\title{
PENGARUH KONSELING KARIER TERHADAP PENINGKATAN EFIKASI DIRI PADA SISWA SMP 12 BANJARMASIN
}

\author{
Dina Aprilia \\ Dosen Jurusan Psikologi Islam \\ Fakultas Ushuluddin dan Humaniora IAIN Antasari Banjarmasin
}

\begin{abstract}
This study is aimed at determining the effect of career counselling on increasing self efficacy among Junior High School Students. To find the effect, this study investigates two group of students. The first group is those who got the conselling career, while the second group did not. The result is that those who got conselling career have higher self efficacy than those who did not. This means that career counselling truly increases self efficacy in career making decision among the students.
\end{abstract}

Kata kunci: efikasi diri, keputusan karier, konseling karir

\section{Pendahuluan}

Pendidikan, lapangan pekerjaan, pengangguran merupakan permasalahan besar yang ada di Indonesia. Rendahnya mutu pendidikan ditambah susahnya mencari pekerjaan, kemiskinan, dan sedikitnya lowongan pekerjaan yang tersedia menjadi salah satu latar belakang tercetusnya program yang dibuat pemerintah yaitu SMK BISA oleh Depertemen Pendidikan melalui Direktorat Pembinaan Sekolah Menengah Kejuruan (Dikmenjur). Program ini memiliki tujuan untuk menyiapkan lulusan SMK yang berkualitas dan siap kerja.

Program SMK BISA ini disosialisasikan pemerintah melalui iklan di televisi. Iklan Kementerian Pendidikan Nasional tersebut begitu bersemangat dan bergairah mempromosikan SMK. SMK adalah jalan alternatif meningkatkan kualitas SDM kita, mengurangi angka pengangguran, dengan segala pionir keberhasilan yang ditampilkan dalam iklan tersebut, mulai dari keberhasilan siswa SMK dalam menciptakan mesin yang dikatakan mobil, dan yang paling progresif ditayangkan dalam berbagai kesempatan adalah keberhasilan siswa SMK jurusan TIK yang telah mampu merakit laptop hasil kerjasama dengan produsen lokal dengan sangat bangga pula diberi label SMK, disertai pesan-pesan untuk menggunakan produk dalam negeri agar daya saing nasional meningkat. Iklan tersebut juga menggunakan model-model yang terkenal. Salah satunya Tantowi Yahya seorang publik figur yang mengatakan bahwa dia juga merupakan lulusan SMK dan berhasil menjalani kariernya di masa depan. Model juga merekomendasikan orang lain untuk jangan ragu-ragu masuk SMK terutama siswa SMP yang tertarik melanjutkan ke SMK dan orangtua yang tidak mampu membiayai melanjutkan ke perguruan tinggi (apabila memilih SMA).

Namun kenyataannya pengaruh iklan yang mengakibatkan banyaknya siswa SMP yang memilih SMK tidak sesuai harapan yang menjadikan siswa SMK siap kerja. SDM lulusan SMK dianggap memiliki kemampuan yang masih tanggung, sehingga banyak perusahaan yang tidak menerima lulusan SMK dan akibatnya mereka banyak yang menjadi penganguran. 
Masa remaja merupakan masa peralihan dari masa kanak-kanak menuju ke masa dewasa yang akan mempengaruhi perkembangan individu dalam aspek sosial, emosi, dan fisik. Selanjutnya, remaja juga memiliki tugas-tugas perkembangan untuk persiapan menuju peran sebagai orang dewasa. Pada tahap ini, salah satu tugas perkembangan remaja yang penting menurut Havighurst adalah memilih dan mempersiapkan diri dalam menjalankan suatu pekerjaan. ${ }^{1}$ Oleh sebab itu, pada usia remaja inilah seseorang memasuki tahap membuat keputusan karier. $^{2}$

Remaja membuat rencana karier dengan mengeksplorasi dan mencari informasi berkaitan dengan karier yang diminati. Proses karier tersebut dimulai dari menumbuhkan pemahaman keterkaitan antara kemampuan dirinya dengan tuntutan karier di masa depan. Berkaitan dengan itu, masa remaja telah mencapai tahapan perkembangan kognitif operational formal (11 tahundewasa) yaitu mereka mulai melakukan eksplorasi berbagai alternatif ide dan jurusan dalam cara yang sistematis. ${ }^{3}$ Sedangkan menurut teori perkembangan karier dari Ginzberg. ${ }^{4}$ masa remaja itu termasuk dalam tahap tentatif yaitu mempertimbangkan pilihan karier yang bersifat sementara. Tahapan usia ini adalah masa transisi dari tahapan fantasi pada anak-anak menjadi pengambilan keputusan realistik pada remaja. ${ }^{5}$ Sejalan dengan perkembangan karier tersebut, proses karier telah muncul pada usia sekolah yaitu ketika anak-anak mulai mengembangkan minatnya dan adanya pemahaman keterkaitan antar kemampuan dengan karier di masa depan. Pada usia sekolah, yaitu sejak sekolah dasar sampai sekolah lanjutan, remaja perlu mempelajari keseluruhan keterampilan yang akan membantu dalam usaha membangun kehidupan masa depan. Karier adalah bagian hidup yang berpengaruh pada kebahagiaan hidup manusia secara keseluruhan. Oleh karenanya, ketepatan memilih serta menentukan pilihan karier menjadi titik penting dalam perjalanan hidup manusia.

Winkel ${ }^{6}$ mengatakan career dan vocation lebih menekankan aspek seseorang memandang pekerjaan sebagai panggilan hidup yang meresapi seluruh alam pikiran dan perasaan serta mewarnai seluruh gaya hidupnya (life style). Selain itu, penggunaan istilah karier oleh peneliti mengacu pada orientasi khusus masing-masing jenjang pendidikan sekolah yaitu penyadaran karier untuk sekolah dasar, eksplorasi karier untuk sekolah lanjutan tingkat pertama, dan persiapan karier untuk sekolah lanjutan tingkat atas. Berdasarkan pada teori perkembangan karier oleh Ginzberg ${ }^{7}$ yang memaparkan tahapan perkembangan karier yaitu fantasi (3-11 tahun), tentatif (11-17 tahun), realistik (18-23 tahun), maka peneliti berasumsi bahwa permasalahan karier dapat terjadi sepanjang rentang hidup manusia. Terkait dengan penelitian ini, peneliti menggunakan subjek siswa SMP usia 13-16 tahun, maka orientasi karier jenjang pendidikannnya adalah eksplorasi karier yaitu siswa mengenal dunia kerja dan diri sendiri secara lebih luas dan mendalam. ${ }^{8}$ Pada tahap ini siswa mempelajari bidang-bidang pekerjaan secara lebih mendalam.

\footnotetext{
${ }^{1}$ Sukadji, Psikologi Pendidikan dan Psikologi Sekolah (Jakarta: Universitas Indonesia, 2000), h. 23.

${ }^{2}$ Bardick, et. al., Junior High School Student's Career Plants For the Future (jurnal of career development, 2006), h. 3.

${ }^{3}$ F.P. Rice, Human Development: A Life-Span Approach (Upper Saddle River: Prentice H.1, 2001), h. 4.

${ }^{4}$ J.O. Crites, Vocational Psychology (New York: McGraww-Hill Book Company, 1969), h. 234.

${ }_{5}^{5}$ J.W. Santrock, Perkembangan Remaja (Jakarta : Erlangga, 1986), h. 159.

${ }^{6}$ W.S. Winkel, Bimbingan dan Konseling di Institusi Pendidikan (Jakarta: Gramedia, 2004), h. 111.

${ }^{7}$ J.O. Crites, Vocational Psychology, h. 258

${ }^{8}$ W.S. Winkel, Bimbingan dan Konseling di Institusi Pendidikan, h. 299
} 
Misalnya, orang yang ingin menjadi dokter, maka seharusnya siswa harus berminat di bidang kesehatan, berkemampuan otak tinggi, memiliki sifat tekun dan teliti.

Hurlock ${ }^{9}$ mengungkapkan bahwa besarnya minat remaja terhadap pendidikan sangat dipengaruhi oleh minat mereka terhadap pekerjaan. Jika remaja mengharapkan pekerjaan yang menuntut pendidikan tinggi maka pendidikan dianggap sebagai batu loncatan. Ketika siswa mampu mengenali pilihan pekerjaan yang diinginkan, maka mereka dapat menjalani pendidikan dengan efektif. Orientasi tentang jenis pekerjaan di masa depan merupakan faktor penting yang mempengaruhi minat dan kebutuhan remaja yang akan menjalani pendidikan. ${ }^{10}$ Dapat dikatakan dunia pendidikan bagi remaja dengan menentukkan program pendidikan, fakultas maupun jurusan merupakan pemilihan pendahuluan atau awal dari dunia karier. ${ }^{11}$ Ketertarikan siswa terhadap sekolah dan pekerjaan dapat membantu atau memberikan kesempatan untuk mengembangkan minat, sehingga siswa mampu menentukan pilihan arah pekerjaan nantinya.

Penelitian oleh Santohadi ${ }^{12}$ tentang pengalaman persiapan studi mahasiswa baru menemukan bahwa mahasiswa baru mengalami kebingungan dalam memilih jurusan karena tidak dipersiapkan/direncanakan sejak duduk di bangku sekolah menengah. Penelitian lain menunjukkan hasil yang serupa bahwa pilihan yang dibuat siswa SMP terutama sekali pada saat memilih jenjang pendidikan mempunyai hubungan yang sangat kuat atau memberikan dampak jangka panjang dalam perkembangan pendidikan dan karier dikemudian hari. ${ }^{13}$

Hasil penelitian Chomariah ${ }^{14}$ tentang kematangan karier siswa pada sebuah SMK di Yogyakarta menunjukkan bahwa siswa kurang memiliki pengetahuan tentang pekerjaan yang akan dijalaninya setelah lulus SMK. Hal ini menunjukkan bahwa siswa SMK yang seharusnya sudah memiliki kejelasan yang lebih spesifik tentang tujuan pekerjaan apabila dibandingkan dengan SMA umum. Namun pada kenyataannya kematangan karier yang dimiliki siswa SMK masih sangat kurang. Berdasarkan penelitian tersebut juga didapatkan gambaran bahwa pilihan SMK yang dijalani tidak relevan dengan pekerjaan yang mereka inginkan. Akibat yang ditimbulkan dari ketidakmatangan karier banyak dari siswa SMK memilih pekerjan yang tidak sesuai dengan latar belakang pendidikannya atau sebaliknya menjalani pendidikan SMK dengan tidak maksimal, misalnya kesulitan dalam pelajaran dan sering tidak naik kelas.

Bardick, dkk ${ }^{15}$ mengungkapkan bahwa terdapat dua pilihan yang mungkin diambil siswa dalam pengambilan keputusan karier, yaitu antara bekerja atau melanjutkan studi. Jika siswa tidak merencanakannya, maka terdapat konsekuensi kegagalan pada siswa. Untuk melengkapi temuan-temuan sebelumnya, peneliti untuk selanjutnya akan memfokuskan permasalahan pengambilan keputusan karier di SMP 12 sebagai tempat penelitian. Alasan pemilihan SMP 12 sebagai tempat penelitian antara lain peneliti menemui fakta berdasarkan observasi dan

${ }^{9}$ E.B. Hurlock, Psikologi Perkembangan (Jakarta: Gelora Aksara Pratama, 1999), h. 17.

${ }^{10}$ Desmita, Psikologi Perkembangan (Bandung: Remaja Rosda Karya, 2005), h. 23.

${ }^{11}$ Sukadji, Psikologi Pendidikan dan Psikologi Sekolah, h. 21

${ }^{12}$ F. Santohadi, "Pengalaman Persiapan Pilihan Studi/Karir Mahasiswa USD Semester 1.”( Tesis tidak diterbitkan, 2006), h. 5 .

13. Trusty, et. al., Educational Career Planning and Middle School Counselor, (jurnal of career development, 2006), h. 8.

${ }^{14}$ T. Chomariah, "Pelatihan Perencanaan Karir untuk Meningkatkan Kematangan Karir pada Siswa SMK," (Tesis tidak diterbitkan. Magister Psikolog Universitas Islam Indonesia, 2010), h. 23.

${ }^{15}$ Bardick, et. al., Junior High School Student's Career Plants For the Future, h. 11. 
wawancara bahwa siswa SMP 12 belum mendapatkan arahan dan bantuan yang maksimal dalam bimbingan karier dari pihak sekolah. Selain itu, kondisi ekonomi menengah ke bawah sebagian besar keluarga siswa, sehingga siswa memiliki tujuan untuk bekerja setelah menyelesaikan sekolah. Hal ini cukup menjadi alasan peneliti untuk menjadikan SMP 12 sebagai tempat penelitian dengan tujuan membantu siswa-siswa dalam pengambilan keputusan karier.

Berdasarkan data survey awal kebingungan dan keraguan siswa dalam memilih SMK disebabkan oleh belum yakin dengan kemampuannya untuk mencapai pekerjaan yang akan dipilih, sehingga siswa mengalami kebingungan dalam memilih SMK yang sesuai dengan kemampuan dan pekerjaan yang akan dijalaninya nanti. Hal ini dijadikan alasan kuat bagi peneliti bahwa dalam penelitian ini fokusnya adalah membantu siswa untuk yakin dengan pengambilan keputusan karier yang sesuai dengan kemampuan yang dimilikinya. Peneliti memberikan batasan pengambilan keputusan karier yang disesuaikan dengan perkembangan siswa SMP sebagi remaja yaitu mengarah pada pengambilan keputusan pekerjaan dan belum membahas pada tahap pengenalan jenjangjenjang dalam karier secara mendalam. Hal ini didasarkan pada tahap perkembangan karier siswa $\mathrm{SMP} /$ remaja menurut Ginzberg ${ }^{16}$ merupakan perkembangan karier tentatif, sehinggga karier yang dimaksud hanya mengeksplorasi masalah pekerjaan yang bersifat sementara.

Ketidakmampuan siswa SMP dalam pengambilan keputusan karier menggambarkan bahwa efikasi diri dalam pengambilan keputusan karier yang rendah. Aspek keyakinan akan kemampuan diri merupakan salah satu karakter kepribadian yang dikenal dengan sebutan efikasi diri. Indikasi yang ditunjukkan siswa kelas IX SMP 12 ini bertentangan dengan ciri-ciri individu dengan efikasi diri yang tinggi dalam pengambilan keputusan karier yaitu memiliki keyakinan diri bahwa dapat membuat penilaian diri dengan tepat, yaitu mengetahui kelebihan dan kelemahan dirinya; mampu mengumpulkan informasi-informasi yang berhubungan dengan pekerjaan; dapat memilih suatu tujuan karier yang tepat berdasarkan informasi-informasi yang diolah dengan baik, mampu membuat suatu perencanaan karier yang tepat dan disesuaikan dengan tujuan karier jangka pendek maupun jangka panjang; serta memecahkan permasalahanpermasalahan yang berkaitan dengan pencapaian kariernya.

Efikasi diri dalam pengambilan keputusan karier diangkat oleh peneliti sebagai tema dalam penelitian dengan alasan antara lain: walaupun siswa yang duduk di bangku SMP masih berada pada tahap perkembangan karier tentantif (sementara), namun berdasarkan penelitan sebelumnya dan survey awal peneliti di SMP 12 sebagai tempat penelitian maka peneliti merasa perlu penanganan sejak dini terkait dengan pengambilan keputusan karier (dalam konteks pekerjaan). Hal ini sebagai tindakan preventif agar siswa yang memutuskan untuk langsung bekerja setelah lulus dari SMK tidak mengalami salah memilih jurusan SMK yang sesuai dengan tujuan pekerjaannya. Hal ini seperti yang dikemukakan Creed, dkk. ${ }^{17}$ bahwa tidak semua siswa dapat mengambil keputusan dengan mudah untuk memilih karier yang akan dijalaninya karena kebanyakan mereka mengalami fase kebingungan sebelum menetapkan pilihan karier. Ketidakmampuan individu dalam membuat keputusan dapat dipengaruhi oleh efikasi diri

${ }^{16}$ J.O. Crites, Vocational Psychology, h. 276.

${ }^{17}$ P.W. Creed, et. al., Causal Relationship between Career Indecision and Career Decision Making Self Efficacy, Jurnal of career development, 2006), h. 6. 
terhadap pengambilan keputusan karier. ${ }^{18}$ Banyaknya pilihan jurusan SMK tentunya juga menimbulkan kebingungan bagi siswa jika sejak awal belum mengetahui kemampuan yang dan tujuan pekerjaan. Hal ini akan mengakibatkan siswa mengambil jurusan yang tidak tepat. Kondisi ini memberikan dampak negatif jangka panjang, antara lain menjalankan pendidikan tidak maksimal, lulus dalam waktu yang lama. Berdasarkan penelitian diketahui bahwa pilihan yang dibuat siswa SMP terutama memilih jenjang pendidikan mempunyai hubungan yang sangat kuat atau memberikan dampak jangka panjang dalam perkembangan pendidikan dan karier di kemudian hari. ${ }^{19}$

Ranah proses mengacu pada rasa percaya diri dalam kaitannya dengan proses pembuatan keputusan. Efikasi diri yang rendah terkait dengan proses pembuatan keputusan terkait dengan kebimbangan dalam pembuatan keputusan kair, masalah-masalah dalam mengembangkan identitas vokasional yang jelas. Individu dengan efikasi diri yang rendah dalam membuat keputusan karier dapat ditandai dengan ketidaktahuan terhadap kelebihan dan kelemahan dirinya, tidak mendapatkan informasi yang berhubungan dengan karier.

Efikasi diri memegang peranan penting dalam pengambilan keputusan karier. Taylor dan Betz $^{20}$ mengatakan bahwa efikasi diri terhadap pengambilan keputusan karier mempengaruhi area-area dari perilaku pencapaian karier, termasuk kemampuan untuk mengejar ketertarikan karier dan ketekunan terhadap pencapaian karier tesebut. Efikasi diri merupakan indikator yang penting dalam penentuan karier. ${ }^{21}$ Bandura melalui teori kognitifnya mengungkapkan bahwa efikasi diri adalah kepercayaan/keyakinan seseorang mengenai kemampuannya untuk sukses dalam melaksanakan satu tugas yang diberikan. ${ }^{22}$ Efikasi diri yang ditumbuhkan secara terus menerus, akan membantu dalam mencapai tujuan jangka panjang yaitu menghadapi halangan, kegagalan dan hambatan dari lingkungan yang menghambat pencapaian misalnya gender atau adanya diskriminasi ras. ${ }^{23}$ Adanya kepercayaan diri akan menentukan pilihan yang dibuat dan tindakan yang akan diambil. ${ }^{24}$ Kepercayaan diri tersebut dapat menjadi motivasi bagi siswa untuk mencapai masa depan karier yang diinginkannya. Dengan kata lain, efikasi diri dalam pengambilan keputusan karier atas adalah keyakinan individu terhadap kemampuan dirinya bahwa siswa kelas IX dapat sukses menyelesaikan tugas-tugas yang berhubungan dengan efikasi diri terhadap pengambilan keputusan karier, termasuk di dalamnya penentuan jurusan SMK yang dipilih.

Berdasarkan survey awal, peneliti menemui fenomena yang terjadi di kalangan siswa SMP 12, yaitu ketidakyakinan dengan kemampuan yang dimiliki terkait dengan pemahaman diri, informasi pekerjaan, bingung memilih SMK yang sesuai dengan minat pekerjaan dan kemampuan yang dimiliki. sehingga siswa mengalami keraguan/ketidakyakinan mengambil keputusan karier (Efikasi diri dalam pengambilan keputusan karier yang rendah). Individu dengan efikasi diri yang rendah dalam membuat keputusan karier memerlukan intervensi karier yang

\footnotetext{
${ }^{18}$ N.E. Betz and K.M. Taylor, Evaluation of a Short Form of the Career Decision-Making Self Efficacy Scale, (Jurnal of career development, 1996), h. 7.

${ }^{19}$ Bardick, et. al., Junior High School Student's Career Plants For the Future, h. 4.

${ }^{20}$ N.E. Betz and K.M. Taylor, Evaluation of a Short Form of the Career Decision-Making Self Efficacy Scale, h. 5.

${ }^{21}$ A. Bandura, Self Efficacy, (New York: W.H Freeman Company, 1997), h. 126.

${ }^{22}$ P.W. Creed, et. al., Causal Relationship between Career Indecision and Career Decision Making Self Efficacy, h. 8.

${ }^{23}$ N.E. Betz and K.M. Taylor, Evaluation of a Short Form of the Career Decision-Making Self Efficacy Scale, h. 4.

${ }^{24}$ L.H. Tuck, et. al., Career Pattern, (Ohio: Prantice H.l, 2004), h. 3.
} 
tepat. Hasil penelitian yang dilakukan Fukuyana, Probert, Neimeyer, Nevill \& Metzler, 1998; McNeill, 1990; Foltz, 1993; Luzzo \& Taylor, 1994) menunjukkan efektivitas intervensi karier dalam meningkatkan efikasi diri dan menurunkan ketidakmampuan dalam membuat keputusan karier (dalam Betz \& Luzzo, 1996). Intervensi karier dapat berupa konseling (Betz, 2000).

Siswa yang memiliki efikasi diri rendah ditunjukkan masih belum bisa membuat perencanaan karier dalam hidupnya. Siswa belum yakin dengan kemampuan yang dimilikinya, sehingga menjadikan siswa belum bisa menggambarkan keinginan konkrit dalam merealisasikan pekerjaan yang diinginkan. Perencanaan karier yang dimaksudkan adalah suatu perencanaan yang menuntut pemikiran tentang segala tujuan yang ingin dicapai dalam jangka panjang (long-range goals) dan semua tujuan yang ingin dicapai dalam jangka pendek (short-range goals) ${ }^{25}$. Secara ideal, tujuan jangka panjang siswa SMP adalah menentukan pilihan karier yang akan dijalani pada masa akan datang. Namun sebelum tujuan jangka panjang diraih, siswa harus menentukan tujuan jangka pendek yang sekaligus akan menjadi jalan untuk mencapai tujuan jangka panjangnya serta kesesuaian dengan kemampuan yang dimilikinya. Aspek perencanaan karier memberikan pemahaman berupa kemampuan yang dimiliki dan informasi tentang karier termasuk di dalamnya pendidikan (tujuan jangka pendek) dan pekerjaan (tujuan jangka panjang).

Konseling kelompok dilandasi keinginan untuk membantu para siswa mulai memikirkan kehidupan masa depannya dalam hal ini memutuskan karier/pekerjaan yang akan dipilihnya. Peneliti memilih konseling alasan utamanya adalah bahwa pemecahan masalah yang terjadi di sekolah, termasuk karier difasilitasi oleh guru BK melalui media konseling individual maupun kelompk, sehingga memudahkan bagi pihak sekolah untuk dapat menjalankannya secara berkesinambungan. Betz $^{26}$ mengungkapkan bahwa intervensi dalam bentuk konseling adalah efektif untuk meningkatkan efikasi diri dalam pengambilan keputusan karier dan mengurangi keragu-raguan.

Pendekatan kelompok sangat efektif untuk digunakan pada usia remaja, karena usia remaja sangat memerlukan dukungan dan dorongan dari teman sebaya. Pendekatan Kelompok juga memberikan umpan balik yang sangat diperlukan oleh seorang remaja (Resse \& Miller, 2006). Konseling yang diberikan ini diharapkan memudahkan siswa dalam menyerap semua informasi yang diberikan, karena adanya umpan balik dan dukungan dari orang lain yang juga berusia remaja. Konseling kelompok perencanaan karier diharapkan mampu menjadi sarana diskusi tentang permasalahan yang dialami siswa dalam perencanaan karier masa depannya.

Melalui media kelompok siswa akan lebih mudah menyerap informasi dan menerima umpan balik dari konselor dan sesama anggota kelompok tentang pemahaman dirinya, pekerjaan yang diinginkan untuk masa depan, SMK yang sesuai dengan kemampuannya, dan mengatasi permasalahan yang menghambat dalam pencapaian rencana tersebut. Hal ini akan membantu meningkatkan efikasi diri dalam pengambilan keputusan karier pada siswa SMP, sehingga siswa menjadi yakin dan mantap dalam memilih Sekolah lanjutan tingkat atas yang diinginkannya. Efikasi diri tersebut berpengaruh terhadap perilaku meliputi proses kognitif, proses motivasional, proses afektif, dan proses seleksi. ${ }^{27}$

\footnotetext{
${ }^{25}$ W.S. Winkel, Bimbingan dan Konseling di Institusi Pendidikan, h. 277.

${ }^{26}$ N.E. Betz and K.M. Taylor, Evaluation of a Short Form of the Career Decision-Making Self Efficacy Scale, h. 6.

${ }^{27}$ A. Bandura, Self Efficacy, h. 165.
} 
Berdasarkan latarbelakang masalah tersebut, pertanyaan peneliti adalah apakah konseling kelompok perencanaan karier memberikan pengaruh terhadap peningkatan efikasi diri dalam pengambilan keputusan SMK bagi siswa kelas IX SMP 12.

\section{Efikasi Diri dalam Pengambilan Keputusan Karier}

\section{Definisi Efikasi Diri dalam Pengambilan Keputusan Karier}

Efikasi diri menurut Bandura ${ }^{28}$ adalah keyakinan individu akan kemampuannya untuk melakukan suatu tugas dengan berhasil pada tingkat tertentu atau dengan kata lain keyakinan individu bahwa dirinya mampu melakukan suatu tindakan yang diperlukan untuk mencapai suatu tujuan tertentu dengan berhasil. Baron dan Byrne ${ }^{29}$ mendefinisikan efikasi diri sebagai evaluasi/penilaian seseorang mengenai kemampuan atau kompetisi dirinya untuk melakukan suatu tugas untuk mencapai tujuan atau untuk mengatasi hambatan dan penilaian pribadi bahwa dirinya adalah orang yang mampu melakukan tindakan yang tepat.

\section{Dimensi-Dimensi Efikasi Diri dalam Pengambilan Keputusan Karier}

Menurut Taylor dan Betz's ${ }^{30}$ terdapat lima dimensi efikasi diri dalam pengambilan keputusan karier, yaitu :

a. Penilaian kemampuan diri

Penilaian diri yang tepat mengenai kemampuan dan kelemahan diri yang menjadikan memiliki keyakinan dalam mengambil keputusan karier.

b. Pengumpulkan informasi-informasi mengenai karier

Individu mampu mencari informasi tentang pekerjaan yang digunakan untuk mengambil keputusan.

c. Penyeleksian tujuan karier

Individu sudah mempertimbangkan berbagai pilihan karier yang tersedia. Hal ini berdasarkan berbagai hal yang sudah diperoleh dan menggunakan informasi karier yang sudah dimilikinya untuk menentukan tujuan kariernya.

d. Pembuatan rencana karier

Individu mampu menyusun langkah-langkah nyata untuk merencanakan karier.

e. Pemecahan permasalahan karier

Individu mampu mengenali diri dan lingkungannya akan mampu mengatasi semua hambatan yang berkaitan dengan kariernya.

\section{Faktor yang mempengaruhi efikasi diri}

Menurut Bandura ${ }^{31}$ informasi tentang kemampuan diri individu tersebut apakah akurat atau keliru, berdasarkan pada empat sumber, yaitu: (a) Mastery Experience; (b) Vicarious Experience; (c) Verbal Persuation; (d) Physiological State

\footnotetext{
${ }^{28}$ A. Bandura, Self Efficacy, h. 182.

${ }^{29}$ R.A. Baron and Byrne, Social Psychology, (Boston: Allyn and Bacon, 2005), h. 9.

${ }^{30}$ N.E. Betz and K.M. Taylor, Evaluation of a Short Form of the Career Decision-Making Self Efficacy Scale, h. 5.

${ }^{31}$ Bandura, Self Efficacy, h. 85.
} 


\section{Konseling Kelompok Perencanaan Karier}

\section{Pengertian Pendekatan Kelompok}

Menurut Prawitasari ${ }^{32}$ pendekatan kelompok sering digunakan karena memiliki beberapa kelebihan, yaitu: 1) Kelompok memberikan kesempatan bagi anggotanya untuk saling memberi dan menerima umpan balik, 2) Di dalam kelompok, anggota akan belajar untuk berlatih tentang perilakunya yang baru karena kelompok merupakan mikrokosmik sosial, 3) Kelompok merupakan kesempatan untuk menggali tiap masalah yang dialami anggotanya, 4) Kelompok memberikan kesempatan untuk mempelajari keterampilan sosial, dan 5) Kesempatan memberi dan menerima di dalam kelompok. Selain itu pendekatan kelompok tidak hanya berguna untuk orang-orang yang bermasalah saja tetapi juga berguna untuk orang-orang normal. ${ }^{33}$

\section{Pengertian Diskusi Kelompok}

Jumlah peserta dalam diskusi kelompok akan mempengaruhi jalannya kelompok. Biasanya terdiri dari 6-8 orang dan paling banyak 10 orang. Jumlah anggota kelompok yang terlalu besar juga akan mengurangi keaktifan masing-masing peserta dan mengurangi tanggung jawabnya untuk turut serta mencapai hasil yang diharapkan. Sebaliknya apabila jumlah anggota kurang dari 6 orang ada kecenderungan dalam kelompok untuk mudah terpengaruh oleh anggota lain, sehingga pemecahan masalah tidak sesuai yang diharapkan. ${ }^{34}$

Berdasarkan uraian tersebut di atas jumlah anggota diskusi kelompok pada penelitian ini berjumlah 6-10 orang yang membahas mengenai suatu topik dengan waktu antara 45-120 menit untuk mendapatkan satu kesimpulan.

\section{Perencanaan Karier}

a. Definisi Perencanaan Karier

Perencanaan merupakan suatu kegiatan untuk mempertimbangkan melakukan hal-hal yang hendak dicapai dan membuat langkah-langkah pencapaiannya. Dalam konteks perencanaan karier, seseorang akan melakukan perencanaan dalam rangka mencapai tujuan karier tertentu.

b. Aspek Perencanaan karier

Konseling perencanaan karier ini disusun Menurut Aryatmi, ${ }^{35}$ secara garis besar ada beberapa langkah dalam perencanaan karier, yaitu:

1) Memilih karier secara tentatif atu pilihan karier yang bersifat sementara.

2) Mengenal diri sendiri, yaitu meliputi bakat, minat, kemampuan atau prestasi di bidang akademik atau non-akademik yang berhubungan dengan karier.

3) Mengenal lingkungan atau dunia kerja.

4) Menguji atau membandingkan pilihan tentatif karier dan memutuskan pilihan pekerjaan yang paling sesuai dan tepat dengan kondisi dirinya.

5) Membuat rencana atau langkah-langkah mencapai tujuan karier.

\footnotetext{
32J. E. Prawitasari, Pendekatan Kelompok dalam Konseling dan Psikoterapi, (Malang: IKIP Malang, 1991), h. 19.

${ }^{33}$ Prawitasari, Pendekatan Kelompok dalam Konseling dan Psikoterapi, h. 15.

${ }^{34}$ J. Bulatau, Teknik Diskusi Berkelompok, (Yogyakarta: Kanisius, 1971), h. 25.

${ }^{35}$ S. Aryatmi, Perspektif Bimbingan Konseling dan Penerapannya di Berbagai Instansi, (Semarang: Satya Wacana, 1991), h. 37.
} 
6) Mempelajari langkah-langkah, keterampilan dan sikap yang diperlukan dalam pencapaian karier.

7) Menyesuaikan diri terhadap pekerjaan.

Konseling perencanaan karier yang dibuat oleh peneliti berdasarkan konsep yang dikemukakan Aryatmi ${ }^{36}$ dan dibagi menjadi 7 sesi konseling, yaitu :

1) Masa depanku yang bertujuan untuk menumbuhkan arti pentingnya perencanaan karier.

2) Pemahaman diri yang bertujuan untuk mengenal kepribadian, minat, nilai-nilai, kemampuan dan tujuan-tujuan masa depan.

3) Pekerjaanku idamanku bertujuan untuk mengkaitkan pilihan minat karier masa depan dengan pemilihan sekolah lanjutan atas.

4) Antisipasi masalah dan pemecahan masalah yaitu mengidentifikasi masalah yang muncul dalam pengambilan keputusan dan perencanaan karier.

5) Aku bisa 1, bertujuan untuk membangun komitmen dan bersungguh-sungguh dalam memperjuangkan cita-cita.

6) Aku bisa 2, bertujuan untuk mengontrol emosi yang ada di dalam diri peserta terkait dengan pencapaian cita-cita.

7) Pengambilan keputusan dan menyusun perencanaan karier, bertujuan membuat langkah-langkah konkrit untuk mencapai cita-citanya.

\section{Hipotesis Penelitian}

Berdasarkan teori-teori dan penelitian-penelitian yang telah diuraikan, maka diajukan hipotesis: ada perbedaan tingkat efikasi diri dalam pengambilan keputusan karier sebelum (pretest) dan setelah (posttest), antara subjek kelompok eksperimen dan subjek kelompok kontrol setelah diberikan konseling perencanaan karier. Subjek pada kelompok eksperimen mengalami kenaikan tingkat efikasi dalam pengambilan keputusan karier yang lebih tinggi dibandingkan dengan kelompok kontrol.

\section{Metode Penelitian}

\section{Rancangan Penelitian}

Penelitian ini merupakan penelitian between group design - pretest-posttest control group design ${ }^{37}$ yaitu suatu metode eksprimen yang berusaha untuk membandingkan efek suatu perlakuan terhadap variabel tergantung yang diuji dengan cara membandingkan keadaan variabel tergantung pada kelompok eksperimen setelah dikenai perlakuan dengan kelompok kontrol yang tidak diberi perlakuan

Penelitian ini dilakukan pada dua kelompok yaitu kelompok eksperimen dan kelompok kontrol. Kelompok eksperimen mendapatkan intervensi atau perlakuan berupa konseling kelompok perencanaan karier. Kelompok kontrol diperlakukan sebagai waiting list yang akan diberi konseling kelompok perencanaan karier sesuai dengan yang diberikan kepada kelompok eksperimensetelah seluruh proses penelitian berakhir. Kelompok kontrol diberikan konseling

\footnotetext{
${ }^{36}$ S. Aryatmi, Perspektif Bimbingan Konseling dan Penerapannya di Berbagai Instansi, Aryatmi, h. 39.
}

${ }^{37}$ S. Azwar, Metode Penelitian, (Yogyakarta: Pustaka Pelajar, 1998), h. 46. 
kelompok perencanaan karier seperti halnya kelompok eksperimen yaitu sebanyak 6 pertemuan dengan materi dan konselor yang sama dengan pemberian konseling pada kelompok eksperimen.

\section{Identifikasi Variabel Penelitian}

a. Variabel bebas (intervensi) : konseling kelompok perencanaan karier

b. Variabel tergantung (pengukuran) : efikasi diri dalam pengambilan keputusan karier

\section{Subjek Penelitian}

Subjek dalam penelitian ini adalah siswa kelas IX SMP 12 yang memiliki karakteristik sebagai berikut :

a. Memiliki tingkat efikasi diri rendah dalam pengambilan keputusan karier (pretest).

b. Usia berkisar antara 13-16 tahun.

c. Memiliki keinginan untuk melanjutkan ke SMK.

\section{Metode Pengumpulan Data/Pengukuran}

Metode yang digunakan dalam penelitian ini adalah pengukuran pretest dan posttest dengan menggunakan Skala Efikasi diri dalam pengambilan keputusan karier. Skala ini disusun oleh peneliti dengan memodifikasi skala efikasi diri dalam pengambilan keputusan karier (Career Decision Making Self Efficacy Scale) versi Taylor dan Betz's. ${ }^{38}$ Skala ini disusun berdasarkan lima dimensi efikasi diri dalam pengambilan keputusan karier, yaitu penilaiain tentang kemampuan diri, pengumpulan informasi-informasi mengenai karier, penyeleksian tujuan karier, pembuatan rencana-rencana karier, dan pemecahan permasalahan karier.

\section{a. Alat/ Materi Penelitian}

1) Panduan Konseling Kelompok Perencanaan Karier

Konseling perencanaan karier ini dimodifikasi berdasarkan kerangka berpikir yang dibuat oleh Aryatmi. ${ }^{39}$

2) Persetujuan subjek (Informed Concent)

Merupakan lembar persetujuan subjek, yang memuat hak dan kewajiban yang harus dilakukan oleh subjek, serta manfaat yang diperoleh subjek.

3) Lembar observasi

Observasi konseling pada semua sesi dalam konseling agar dapat diperoleh gambaran secara lengkap tentang perilaku peserta selama konseling berlangsung. Aspek-aspek yang teramati dalam observasi meliputi: a) Mengusulkan; b) Mencari gagasan; c) Mengajukan pertanyaan; d) Memberikan informasi; e) Merangkum; f) Menyela; g) Mempersilakan bicara; h) Menyimak; i) Menyerang ; j)mengobrol dengan teman ; k) Mencatat materi.

4) Lembar evaluasi konseling

Lembar evaluasi harian konseling mengungkap tanggapan subjek tentang proses konseling yang berlangsung, meliputi: a) Penyelenggaraan konseling; b) Konselor; c) Materi.

\footnotetext{
${ }^{38}$ N.E. Betz and K.M. Taylor, Evaluation of a Short Form of the Career Decision-Making Self Efficacy Scale, h. 7.
}

${ }^{39}$ S. Aryatmi, Perspektif Bimbingan Konseling dan Penerapannya di Berbagai Instansi, Aryatmi, h. 9. 
Sebelum digunakan dalam penelitian, panduan konseling perencanaan karier terlebih dahulu ditinjau kelayakannya melalui professional judgement. Professional judgment dilakukan dengan mendiskusikan materi panduan bersama dengan dua orang dosen pembimbing tesis peneliti, 1 orang dosen psikologi pendidikan dan satu orang konselor. Professional judgment dilakukan untuk mengetahui apakah materi konseling, alokasi waktu, bahasa yang digunakan tepat sehingga sesuai dengan tujuan konseling.

a) Penyusunan alat ukur dan uji coba alat ukur.

Penelitian ini menggunakan alat ukur berupa skala efikasi diri dalam pengambilan keputusan karier sebanyak 50 item yang disusun oleh peneliti berdasarkan CDMSE. ${ }^{40}$

b) Pemberian pretest skala efikasi diri dalam pengambilan keputusan karier.

Pretest skala efikasi diri dalam pengambilan keputusan karier diberikan kepada semua siswa kelas IX SMP 12. Hal ini dilakukan sekaligus untuk menyeleksi subjek (Screening) yang sesuai dengan kriteria penelitian.

c) Penandatanganan persetujuan subjek

Subjek menandatangani surat persetujuan berisi penjelasan penelitian, keadaan, ketentuan, manfaat, resiko, jaminan kerahasiaan identitas dan komitmen subjek untuk mengikuti seluruh tahapan konseling sampai selesai sebelum mengikuti penelitian.

b. Pelaksanaan Penelitian (Pemberian Intervensi)

Intervensi hanya diberikan kepada kelompok eksperimen yaitu berupa konseling kelompok perencanaan karier sebanyak 6 kali pertemuan. Sedangkan, pada kelompok kontrol tidak diberikan intervensi berupa konseling perencanaan karier. Namun, diberlakukan sebagai waiting list setelah penelitian ini selesai.

\section{Metode Analisis Data}

Analisis data utama adalah metode kuantitatif dan analisis data pendukung digunakan metode kualitatif. Data skor yang didapatkan dari skala efikasi diri dalam pengambilan keputusan karier dianalisis secara kuantitatif dengan menggunakan teknik statistik perangkat lunak Statistical Product and Service Solution (SPSS) for Windows Versi 17,00 dengan menggunakan analisis uji-t (uji beda). Sedangkan data observasi, wawancara, lembar kerja merupakan data pendukung yang dianalisis menggunakan metode kualitatif.

\section{Pelaksanaan dan Hasil Penelitian}

\section{Pelaksanan Penelitian}

Intervensi pada penelitian ini adalah dengan konseling perencanaaan karier. Kelompok eksperimen mengikuti konseling perencanaan karier sebanyak 6 sesi konseling. Sesi konseling berlangsung 90 menit setiap sesi dan dipimpin oleh konselor yang sudah berpengalaman dalam melakukan konseling. Adapun jadwal pelaksanaan intervensi berupa konseling perencanaan karier untuk meningkatkan efikasi diri dalam pengambilan keputusan karier pada siswa kelas IX SMP 12

\footnotetext{
${ }^{40}$ N.E. Betz and K.M. Taylor, Evaluation of a Short Form of the Career Decision-Making Self Efficacy Scale, h. 8.
} 


\section{Hasil Penelitian}

\section{Analisis Kuantitatif}

\section{a. Deskripsi Statistik}

Data dalam penelitian ini mendeskripsikan 20 subjek penelitian, 10 orang kelompok eksperimen diberikan konseling perencanaan karier dan 10 orang kelompok kontrol tidak diberikan perlakuan apapun, namun itu kelompok kontrol juga diberlakukan waiting list dalam pemberian konseling perencanaan karier. Deskripsi data skor efikasi diri dalam pengambilan keputusan karier tergambar dalam pada tabel 6 berikut:

\section{Deskipsi Data Hasil Penelitian}

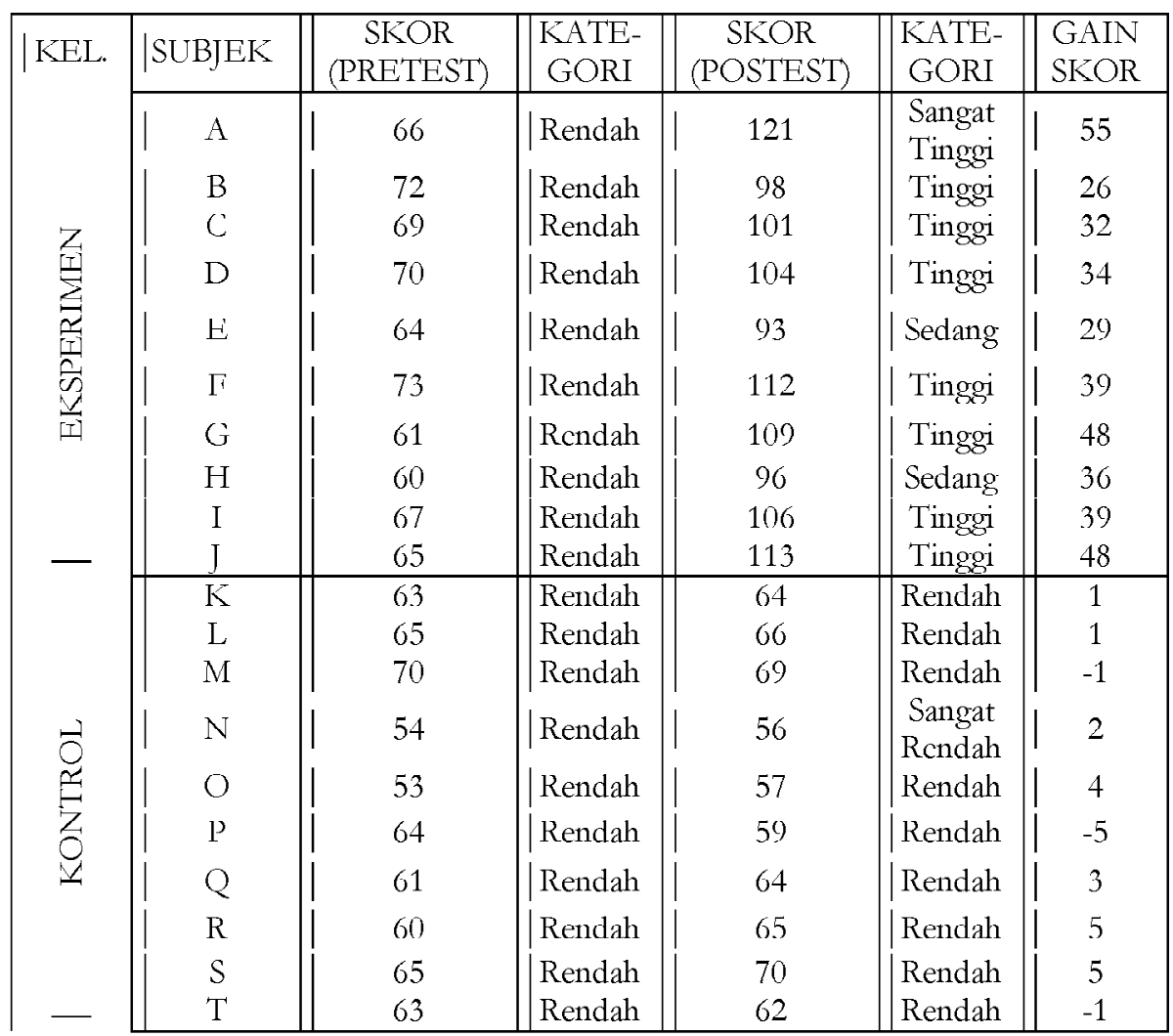

Berdasarkan deskripsi data subjek penelitian yang diperoleh, maka dapat dideskripsikan secara statistik dapat dilihat sebagai berikut:

\section{Deskripsi Statistik Subjek Penelitian}

\begin{tabular}{|c|c|c|c|c|}
\hline & \multicolumn{2}{|c|}{ Kelompok Tksperimen } & \multicolumn{2}{|c|}{ Kelompok Kontrol } \\
\hline & Pretest & Posttes & Pretest & Posttest \\
\hline $\mathrm{N}$ & 10 & 10 & 10 & 10 \\
\hline Mean & 66,70 & 105,30 & 61,80 & 63,20 \\
\hline $\mathrm{SD}$ & 4,373 & 8,667 & 5,138 & 4,733 \\
\hline Min & 60 & 93 & 53 & 56 \\
\hline Max & 73 & 121 & 70 & 70 \\
\hline
\end{tabular}


Analisis data skor kelompok eksperimen menunjukkan ada peningkatan rerata sebesar 38, 6 (Pretest $=66,70$ dan posttest $=105,30)$. Sedangkan analisis data skor kelompok kontrol menunjukkan suatu penaikan rerata yang relatif kecil yaitu 1, 4 (Pretest $=61,80$ dan posttest $=63,20)$.

\section{b. Uji Hipotesis}

1) Kelompok Eksperimen (Uji Beda Pretest-PosttestPaired-Samples t test)

Uji Beda pada kelompok Eksperimen Paired Samples Test

\begin{tabular}{llllll}
\hline & Mean & Stcl. Deviasi & $\mathrm{T}$ & $\begin{array}{l}\text { Sig. } \\
\text { tailed })\end{array}$ & $(2-$ \\
\hline Fifikasi Pretest-Pasttest & -38.600 & 9.240 & -13.210 & 0,000 & \\
\hline
\end{tabular}

Uji beda yang dilakukan pada kelompok eksperimen mendapatkan nilai $\mathrm{t}=-13,210$ dan $\mathrm{p}=0,000, \mathrm{p}<0,01$, artinya ada perbedaan skor efikasi diri dalam pengambilan keputusan karier yang sangat signifikan antara sebelum dan sesudah konseling perencanaan karier. Perbedaan kondisi tingkat efikasi diri dalam pengambilan keputusan karier subjek kelompok eksperimen, sebelum (pretest) dan setelah (posttest) diberikan intervensi.

2) Kelompok Kontrol (uji beda pretest-posttestPaired-Samples t test)

Tabel

Uji Beda pada kelompok Kontrol Paired Samples Test

\begin{tabular}{lllll}
\hline Mean & $\begin{array}{c}\text { Std. } \\
\text { Deviasi }\end{array}$ & t & $\begin{array}{c}\text { Sig. } \\
\text { (2-tailed) }\end{array}$ \\
\hline Efikasi Pretest-Posttest & -1.400 & 3.134 & -1.413 & 0,191 \\
\hline
\end{tabular}

Hasil statistik pada kelompok kontrol didapatkan nilai $\mathrm{t}=-1,400$ dan $\mathrm{p}=0,191, \mathrm{p}$ $>0,05$, artinya tidak ada perbedaan efikasi diri dalam pengambilan keputusan karier yang signifikan.

Perbedaan kondisi tingkat efikasi diri dalam pengambilan keputusan karier subjek kelompok kontrol, sebelum (pretest) dan setelah (posttest) diberikan intervensi.

3) Uji Pengaruh konseling perencanaan karier antara kelompok eksperimen dengan kelompok kontrol

Tabel

Uji Pengaruh Konseling Perencanaan Karir antara Kelompok Eksperimen dan Kelompok Kontrol (t Independent-Samples T test)

\begin{tabular}{|c|c|c|c|c|c|c|c|}
\hline \multicolumn{3}{|c|}{ Kelompok } & \multirow{2}{*}{$\frac{\mathrm{N}}{10}$} & \multirow{2}{*}{$\frac{\text { Mean }}{38.60}$} & \multirow{2}{*}{$\begin{array}{c}\text { Std. } \\
\text { Deviasi } \\
9.240\end{array}$} & \multirow{3}{*}{$\begin{array}{c}\mathrm{T} \\
12.057\end{array}$} & \multirow{3}{*}{$\begin{array}{c}\begin{array}{c}\text { Sig. } \\
\text { (2-tailed) }\end{array} \\
0.000\end{array}$} \\
\hline \multirow{2}{*}{$\begin{array}{l}\text { GS } \\
\text { diri }\end{array}$} & \multirow[t]{2}{*}{ Efikasi } & Eksperimen & & & & & \\
\hline & & Kontrol & 10 & 1.40 & 3.314 & & \\
\hline
\end{tabular}


Uji beda ini dilakukan untuk mengetahui ada tidaknya perbedaan pengaruh Efikasi Diri dalam Pengambilan Keputusan Karier sebelum dan sesudah konseling perencanaan karier pada kelompok eksperimen dan kelompok kontrol. Perhitungan $t$ didasarkan pada equal varians assumed (diasumsikan kedua varian sama) menghasilkan $\mathrm{t}=12,057$ dan $\mathrm{p}=0,000, \mathrm{p}<0,01$, artinya adalah ada perbedaan pengaruh efikasi diri dalam pengambilan keputusan karier yang sangat signifikan antara kelompok eksperimen dan kelompok kontrol.

Perbedaan kondisi subjek penelitian, pada pengukuran awal (pretest) dan pengukuran akhir (posttest) antara kelompok eksperimen yang mendapatkan intervensi konseling perencanaan karier dengan kelompok kontrol yang tidak mendapatkan intervensi konseling perencanaan karier, tersaji pada histogram di bawah ini :

Berdasarkan hasil analisis yang telah dilakukan disimpulkan bahwa:

1. Ada perbedaan skor efikasi diri dalam pengambilan keputusan karier yang sangat signifikan antara sebelum dan sesudah konseling perencanaan karier pada kelompok eksperimen.

2. Tidak ada perbedaan skor efikasi diri dalam pengambilan keputusan karier sebelum dan sesudah konseling perencanaan karier pada kelompok kontrol.

3. Ada perbedaan skor efikasi diri dalam pengambilan keputusan karier setelah diberikan konseling perencanaan karier pada kelompok eksperimen dan kelompok kontrol.

\section{Penutup}

Berdasarkan analisis data dan pembahasan yang dilakukan maka dapat disimpulkan bahwa konseling perencanaan karier dalam penelitian ini dapat meningkatkan efikasi diri dalam pengambilan keputusan karier pada siswa kelas IX SMP 12.

\section{DAFTAR PUSTAKA}

Aryatmi, S. Perspektif Bimbingan Konseling dan Penerapannya di Berbagai Instansi. Semarang: Satya Wacana, 1991.

Azwar, S. Metode Penelitian. Yogyakarta: Pustaka Pelajar, 1998.

Bandura, A. Self- Efficacy: The Exercise of Control. New York: W.H. Freeman \& Company, 1997.

Bardick, A.D., Bernes, K.B., Magnusson, K.C., \& Witko, K.D. Junior high School Student's career plans for the future. Journal of Career Development, 32, 250-271, 2006.

Baron, R. A \& Byrne Social Psychology. Boston: Allyn and Bacon, 2005.

Bulatau, J. Teknik Diskusi Berkelompok. cet. 22. Yogyakarta: Kanisius, 1971.

Chomariah, T. "Pelatihan Perencanaan Karir untuk Meningkatkan Kematangan Karir pada Siswa SMK." Tesis tidak diterbitkan. Magister Psikolog Universitas Islam Indonesia, 2010.

Creed, P., Patton, W., \& Prideaux, L. Causal Relationship between Career Indecision and Career Decision Making Self Efficacy. Journal of career development, 33, 47-65, 2006.

Crites, J.O. Vocational Psychology: The Study of Vocational Behavior and Development. New York: McGraww-Hill Book Company, 1969.

Desmita. Psikologi Perkembangan. Bandung: Remaja Rosda Karya, 2005. 
Dhillon, U.\& Kaur, R. Career Maturity of School Children. Journal of Indian Academy of Applied Psychology, 31, 71-76, 2005

Hurlock, E.B. Psikologi Perkembangan: Suatu Pendekatan Sepanjang Rentang Kehidupan. Jakarta: Gelora Aksara Pratama, 1999.

Prawitasari, J. E. Pendekatan Kelompok dalam Konseling dan Psikoterapi. Malang: IKIP Malang, 1991.

Rice, F.P. Human Development: A Life-Span Approach. Upper Saddle River: Prentice Hall, 2001.

Santoadi, F. "Pengalaman Persiapan Pilihan Studi/Karir Mahasiswa USD Semester I," (tidak diterbitkan), 2006.

Santrock, J.W. Perkembangan Remaja. Jakarta: Erlangga, 2003.

Sukadji, S. Psikologi Pendidikan dan Psikologi Sekolah. Lembaga Pengembangan Sarana Pengukuran dan Pendidikan Psikologi Fakultas Psikologi. Jakarta: Universitas Indonesia, 2000.

Trusty, J., Niles, S.G., \&Carney, J.V. Education Career Planning and Middle School Counselor. Professional School Counselling. 9, 136-143, 2005.

Tuck, L.H., Price, A. \& Robertson, M. Career Patterns : A Kaleidoscope of Possibilities. Ohio: Prantice Hall, 2004.

Winkel, W.S. Bimbingan dan Konseling di Institusi Pendidikan. Jakarta: Gramedia, 2004. 